\title{
The effect of acidifying additives on the microbiological stability of feed mixtures
}

\author{
I. Mroczek ${ }^{1}$, A. Frankiewicz ${ }^{1,3}$ and M. Selwet ${ }^{2}$ \\ The August Cieszkowski Agricultural University of Poznań, \\ ${ }^{1}$ Department of Animal Nutrition and Feed Management \\ Wotyńska 33, 60-637 Poznań, Poland \\ ${ }^{2}$ Department of Agricultural Microbiology \\ Wotyńska 35, 60-637 Poznań, Poland
}

\begin{abstract}
Microbiological stability assessment was carried out in 20 samples of PP-grower type mixture during 3-month storage under typical farm conditions. The experimental samples (18 samples) did not contain an antibiotic growth stimulator but they differed with regard to the type and amount of the acidifying additive used preparation. The following preparations were used in the experiment: fumaric acid, sodium formate, Schaumacid, Agricid F, Agro-Cid and Orego-Cid. The acidifying additives used improved the microbiological stability of feeds, especially with regard to the development of Coli and Clostridium bacteria. No clear influence of the above preparations on the growth of yeasts and mould fungi was found.
\end{abstract}

KEY WORDS: feed, acidifying preparations, bacteria, mould fungi

\section{INTRODUCTION}

Feed mixtures contain easily hydrolysed nutrient components and, as such, constitute an excellent environment for the development of undesirable microflora. The most dangerous microorganisms for animals are mould fungi from the genera Aspergillus, Fusarium and Penicillium, since they manufacture a number of strong toxins, which can lead to significant production losses. This danger can be reduced by adding organic acids or their salts to feed mixtures to reduce the threat of development of undesirable microflora during storage, as shown by investigations carried out by Makar et al. (1990). The aim of the performed experiments was to determine the effect of acidifying preparations on the microbiological quality and stability of feeds during storage.

\footnotetext{
$\overline{{ }^{3} \text { Corresponding author: e-mail: frank@jay.au.poznan.pl }}$
} 


\section{MATERIAL AND METHODS}

Twenty 1-kg samples of the PP-grower type of feed mixture were prepared (in laboratory). Individual samples differed from each another with regard to the type and level of the applied feed additive (Table 1). Instead of the antibiotic growth stimulator, D contained the addition of one of the tested acidifying preparations. The individual preparations were added to feed mixtures in amounts recommended by their manufacturers: level $\mathrm{A}=100 \%, \mathrm{~B}=200 \%$, and $\mathrm{C}=300 \%$ of the amount recommended by producers.

Table 1. Experimental design

\begin{tabular}{|c|c|c|c|c|}
\hline \multirow{2}{*}{ Mixture } & \multirow{2}{*}{$\begin{array}{c}\text { Feed } \\
\text { additive } \\
\end{array}$} & \multicolumn{3}{|c|}{ Level in mixtures } \\
\hline & & A & $\mathrm{B}$ & $\mathrm{C}$ \\
\hline $\mathrm{K} 2$ - negative control & Without additive & - & - & - \\
\hline K1 - control & Flavomycin & $25 \mathrm{mg} / \mathrm{kg}$ & - & - \\
\hline D1 - experimental & Fumaric acid & $1.5 \%$ & $3.0 \%$ & $4.5 \%$ \\
\hline D2 - experimental & Sodium formate & $1.5 \%$ & $3.0 \%$ & $4.5 \%$ \\
\hline D3 - experimental & Schaumacid* & $1.5 \%$ & $3.0 \%$ & $4.5 \%$ \\
\hline D4 - experimental. & Agricid F* & $0.8 \%$ & $1.6 \%$ & $2.4 \%$ \\
\hline D5 - experimental & Agro Cid* & $0.3 \%$ & $0.6 \%$ & $0.9 \%$ \\
\hline D6 - experimental & Orego Cid* & $0.2 \%$ & $0.4 \%$ & $0.6 \%$ \\
\hline
\end{tabular}

* - commercial names of multi-component preparations

At the beginning of the experiment, the presence of the following were determined in samples K1 and K2: total bacterial count CFU, yeasts CFU, mould fungi, Salmonella, Clostridium spp. as well as bacteria from the Coli group. Mixture samples were stored for 3 months in paper bags in a piglet house. The same microbiological assays were performed in all of the mixtures after three months of storage. The total bacterial count was determined on Standard Count Agar from Merck. Bacteria from the genus Salmonella were determined on SS Agar from Merck and then tested on XLT 4 Agar, also from Merck. Chromocult Agar was used to assay bacteria from the Coli group, while the presence of Clostridium was tested on TSC Agar supplemented with d-cycloserine, all from Merck. The yeast count was determined on agar with wort, while mould fungi were cultured on Martin substrate with Bengali rouge. All of the inoculations employed the standard plate method from successive dilutions.

\section{RESULTS}

In comparison with the control samples, the addition of the experimental acidifying preparation to the feed mixture reduced the total bacterial count in experimental samples D1, D2, D3 and D4 after 3 months storing the feed (Table 2). Moreover, as the level of the acidifying additive increased in the feed, a 
general trend towards reduction of the total bacterial count was found in samples D1-4. In the case of samples D5 and D6, containing Agro-Cid and Orego-Cid, the total bacterial count either remained on a constant level or increased slightly. The presence of bacteria from the genus Clostridium after 3 months of storage of feed mixtures was found only in control samples K1 and K2. These bacteria were not found in samples D. Also Coli bacteria increased in the control samples, whereas in the experimental samples their levels were lower and depended on the amount of the acidifying preparation added. In the case of D2, already when it was added according to the manufacturer's recommendation (level A), no Coli bacteria were found, in contrast to D4 and D5, when only their highest levels (level C) reduced the Coli count to zero. No bacteria of the Salmonella genus were found in any of the examined samples. The number of mould fungi in all experimental samples (D) was higher and that of yeasts similar to the levels found in control samples.

Table 2. Results of microbiological assays

\begin{tabular}{|c|c|c|c|c|c|c|c|}
\hline Groups & & $\begin{array}{c}\text { Total bacterial } \\
\text { count CFU } \\
\left(\times 10^{4}\right)\end{array}$ & $\begin{array}{l}\text { Yeasts } \\
\text { CFU } \\
\left(\times 10^{3}\right)\end{array}$ & $\begin{array}{c}\text { Mould } \\
\text { fungi } \\
\left(\times 10^{2}\right)\end{array}$ & $\begin{array}{l}\text { Salmonella } \\
\quad\left(\times 10^{1}\right)\end{array}$ & $\begin{array}{l}\text { Clostridium } \\
\text { sp. }\left(\times 10^{3}\right)\end{array}$ & $\begin{array}{l}\text { Coli - group } \\
\quad\left(\times 10^{3}\right)\end{array}$ \\
\hline \multirow{2}{*}{ K2 } & $*$ & 16.6 & 5.20 & 1.20 & 0 & 1.40 & 1.80 \\
\hline & $* *$ & 10.5 & 4.20 & 2.80 & 0 & 2.60 & 5.60 \\
\hline \multirow{3}{*}{ K1 } & $*$ & 12.6 & 5.20 & 0.60 & 0 & 1.80 & 2.80 \\
\hline & ** & 7.90 & 4.70 & 2.50 & 0 & 1.50 & 4.50 \\
\hline & A & 7.12 & 5.50 & 4.50 & 0 & 0 & 3.10 \\
\hline \multirow[t]{3}{*}{$\mathrm{D} 1 * *$} & B & 7.02 & 5.45 & 4.20 & 0 & 0 & 2.01 \\
\hline & $\mathrm{C}$ & 6.92 & 5.25 & 5.40 & 0 & 0 & 1.51 \\
\hline & A & 6.15 & 4.95 & 5.40 & 0 & 0 & 0 \\
\hline \multirow[t]{3}{*}{ D2 ** } & B & 6.02 & 5.12 & 5.06 & 0 & 0 & 0 \\
\hline & $\mathrm{C}$ & 6.00 & 4.85 & 4.90 & 0 & 0 & 0 \\
\hline & A & 6.17 & 4.65 & 5.20 & 0 & 0 & 2.17 \\
\hline \multirow[t]{3}{*}{ D3 $* *$} & B & 6.20 & 4.25 & 5.36 & 0 & 0 & 1.85 \\
\hline & $\mathrm{C}$ & 6.11 & 5.55 & 5.57 & 0 & 0 & 1.11 \\
\hline & A & 7.15 & 6.10 & 5.21 & 0 & 0 & 2.51 \\
\hline \multirow[t]{3}{*}{ D4 ** } & $\mathrm{B}$ & 7.06 & 6.20 & 4.92 & 0 & 0 & 1.78 \\
\hline & $\mathrm{C}$ & 6.44 & 6.02 & 4.65 & 0 & 0 & 0 \\
\hline & A & 7.99 & 5.12 & 6.00 & 0 & 0 & 1.24 \\
\hline \multirow[t]{2}{*}{ D5 ** } & B & 8.02 & 5.67 & 6.20 & 0 & 0 & 1.01 \\
\hline & $\mathrm{C}$ & 8.00 & 6.10 & 5.96 & 0 & 0 & 0 \\
\hline \multirow[t]{3}{*}{ D6 ** } & A & 8.12 & 5.50 & 5.36 & 0 & 0 & 2.12 \\
\hline & B & 8.26 & 4.50 & 4.62 & 0 & 0 & 1.12 \\
\hline & $\mathrm{C}$ & 8.31 & 5.30 & 3.99 & 0 & 0 & 2.10 \\
\hline
\end{tabular}

designations: * initiation of experiments (at start);** after 3 months storing the feed mixture:

level of the acidifing preparation A - 100\%, B - 200\%, C - 300\% recommended by the manufacturer

\section{DISCUSSION}

The obtained results of microbiological assays complied with all of the standards set by the Polish Standard Committee in PN-R-64791, "Feeds, requirements and microbiological examinations". The effectiveness of the added acids or their salts varied (Foeding and Busta, 1991). The microbial effectiveness of formic acid and 
its salts is directed against yeasts and some bacteria, while moulds remain fairly resistant to it (Lueck, 1980). This is partly in keeping with the results of our own studies, on D2 feed samples, which contained 1.5 to $4.5 \%$ sodium formate, where the number of yeasts and the total bacterial count were lower than in the remaining samples. Moreover, no E. coli were found in these samples. No bacteria from the Coli group were cultured from D4 and D5 samples (level C) in which the acidifying additives also contained formic acid. Makar et al. (1990) showed that even low concentrations of formic acid $(21.7 \mathrm{mM})$ were effective against $E$. coli, it can also eliminate Salmonella from contaminated feeds.

\section{CONCLUSIONS}

The examined preparations improved the microbiological stability of feeds, especially with regard to the development of Coli and Clostridium bacteria. No significant influence of the applied preparations on the development of yeasts or mould fungi was observed.

\section{REFERENCES}

Bolduan G., Jung H., Schneider H., Block J., Klenke B., 1988. Influence of propionic and formic acids on piglets. J. Anim. Physiol. Anim. Nutr. 59, 72-78

Foeding P.M., Busta F.F., 1991. Chemical food preservatives. In: Disinfection, Sterilization and Preservation, pp. 802-832

Lueck E., 1980. Antimicrobial Food Additives: Characteristics, Uses, Effects. Springer-Verlag, Berlin (Germany)

Makar A.B., Tephy T.R., Sahin G., Osweiler G., 1990. Formate metabolism in young swine. Toxicol. Appl. Pharmacol. 105, 315-320

Partanen K.H., Mroz Z., 1999. Organic acids for performance enhancement in pigs diet. Nutr. Res. Rev. 12, 117-145

Paulicks B.R., Roth F.X., Kirchgessner M., 1996. Dose effects of potassium difornite (Formi TM LHS) on the performance of growing piglets. Agribiol. Res. 49, 318-326

\section{STRESZCZENIE}

\section{Wpływ dodatku preparatów zakwaszających na stabilność mikrobiologiczną mieszanek paszowych}

Przeprowadzono ocenę stabilności mikrobiologicznej w 20 próbach mieszanki typu PP-grower, po ich przechowaniu przez 3 miesiące w warunkach fermowych. Próby doświadczalne nie zawierały antybiotykowego stymulatora wzrostu, różniły się natomiast rodzajem oraz poziomem dodatku preparatu zakwaszającego. Przedmiotem badań były następujące preparaty: kwas fumarowy (D1), mrówczan sodu (D2), Schaumacid (D3), Agricid F (D4), Agro-Cid (D5) i Orego-Cid (D6). Zastosowane preparaty zakwaszające wpłynęły na poprawę mikrobiologicznej stabilności pasz, zwłaszcza dotyczące rozwoju bakterii z grupy Coli oraz Clostridium. Nie stwierdzono wyraźnego wpływu tych preparatów na rozwój drożdży oraz grzybów pleśniowych. 